\title{
Jdanov, Brecht, Eisler e a Questão do Formalismo
}

\author{
Rubens Ricciardi
}

Nossos primeiros contatos com a música de Hanns Eisler, durante os últimos anos da década de 70 , aconteceram através do Festival Música Nova' ${ }^{1}$, onde tiveram lugar, ao que tudo indica, os primeiros concertos com obras de Eisler no Brasil.

Naquela altura, antes mesmo do nosso curso de graduação junto ao Departamento de Música da ECA-USP, ainda como aluno particular do Prof. Olivier Toni, interessava-nos o estudo das obras dos principais compositores da primeira metade do séc. $X X$ - os pilares da modernidade, referências básicas para a música contemporânea.

Debussy, Bartók, Stravinsky, Shostakovitch, Prokofiev, VillaLobos e a Escola de Viena de Schönberg (sem Eisler!) eram, até então, basicamente os principais objetos de estudo contidos nos livros didáticos que possuíamos ${ }^{2}$. Os modelos de composição musical para a modernidade seriam, portanto, múltiplos.

Mas imediatamente após nossas primeiras reflexões sobre a obra de Eisler, passamos a estudá-lo com especial dedicação. Estávamos na adolescência, ligados aos movimentos estudantis de esquerda, e víamos em Eisler a resposta daquilo que buscávamos como compositor em formação: a união do refinamento técnico da música erudita contemporânea a um contexto ideológico progressista. Em suma, Eisler representaria então, como nenhum 
outro compositor da história da música, a possibilidade de integração da vanguarda estética - sob o ponto de vista da inovação formal e do material musical - com a vanguarda política - e naquela ocasião, entendíamos isto como a luta pela construção de uma sociedade comunista.

Sobre essa temática, lembraríamos aqui algumas frases do escritor alemão Heiner Müller: "Naturalmente o artista não pode prescindir do fato de que ele tenha uma noção de um outro mundo, diferente do real ou do que existe de fato. Caso contrário, não se pode fazer arte. $\mathrm{E}$ assim ofereceu-se esta última religião do séc. $\mathrm{XX}$, a utopia comunista. Não é por acaso: praticamente não há grandes escritores ou artistas que se tenham feito fortes para o nazismo. Mas são muitos em todos os países do mundo que se fizeram fortes em nome desta utopia comunista"3.

De volta a Eisler, ficamos impressionados com a beleza da cantata A mãe (Die Mutter), composta entre 1931 e 1949, primeira obra sua de que tomamos conhecimento. Tratava-se de uma bachiana distinta das de Villa-Lobos, mesmo que se enquadrasse igualmente na linha neoclássica ${ }^{4}$. Composta a partir da tradição do repertório vocal alemão, englobando desde Bach e Schubert até as canções operárias, diferenciava-se originalmente pelo contexto político-revolucionário.

Seguiram-se informações sobre obras de Eisler que até hoje são referências para nossa formação de compositor. Entre outras, destacaríamos: A cantata Diário (Tagebuch), de 1926 - objeto de estudo de nossa dissertação de mestrado junto ao Departamento de Música da ECA-USP. A música para o filme Kuhle Wampe, de 1931, depois adaptada à versão de concerto como Suite $n^{\circ} 3$. As canções políticas dos anos 20 e 30 , imortalizadas com as insuperáveis interpretações de Ernst Busch ${ }^{5}$. As demais canções inseridas na tradição do Lied alemão - como as Seis Canções (Sechs Lieder), de 1922-23, os Recortes de Jornal (Zeitungsausschnitte) de 1925-27 - e as inúmeras canções com textos de Bertolt Brecht, talvez as mais importantes de toda a sua produção vocal. Lembraríamos ainda sua produção instrumental camerística, como 
o Prelúdio e Fuga sobre B-A-C-H (Präludium und Fuge ïber $B-A-C-H)$, de 1934, e as Quatorze maneiras de descrever a chuva (Vierzehn Arten den Regen zu beschreiben), de 1941.

Quanto mais nos aprofundávamos no estudo das obras de Eisler, mais nos intrigavam os diferentes rumos que tomou a sua linha de composição no decorrer do desenvolvimento de sua carreira. Por um lado, víamos com muito interesse suas fases: vienense (1923-1925), berlinense - na República de Weimar (até 1933) - e fase de exílio, na Europa e nos Estados Unidos (até o final da década de 40). Estas três fases caracterizam-se ora pela modernidade estética, como pela originalidade de estilo, com autonomia ou não de Eisler diante da escola a que ele pertence, de maneira não menos importante, como aluno de Schönberg, ao lado de Webern e Berg; e ora pela vitalidade funcional - na tentativa de integração da vanguarda musical com a vanguarda política.

Por outro lado, não compreendíamos por quê Eisler, quando do seu retorno à Europa após a $2^{\mathrm{a}}$ Guerra Mundial, ao se estabelecer em Berlim, RDA - República Democrática Alemã, antiga Alemanha Oriental - teria desenvolvido um repertório, com raras exceções, de tão menor interesse, sem o mesmo contexto revolucionário, sob o ponto de vista tanto estético como ideológico.

Em sua última fase na RDA, de 1949 a 1962, Eisler retomaria em grande parte o estilo folclórico alemão do séc. XIX, com a utilização simplória das funções harmônicas do sistema tonal e, sobretudo, com a insistência nos ritmos de marcha, sem alcançar, no entanto, a criatividade e a expressão de suas canções de luta dos anos 20 e 30. Entre outros exemplos desta fase, em que Eisler curiosamente já não era o compositor da oposição, mas sim da situação, estão As novas canções populares alemãs (Neue deutsche Volkslieder), de 1950, e as cantatas Meio do Século (Mitte des Jahrhunderts), de $1950^{6}$, O exemplo a ser seguido (Das Vorbild), de 1951-52, e os Tapeceiros de Kujan-Bulak (Die Teppichweber von Kujan-Bulak), de 1957.

Até então, Eisler nos parecia um grande ponto de interrogação: como poderia haver tal contradição na obra de um só compositor? 
Como poderia ele ter sido tão ousado e depois tão conservador? O que seria mais significativo ou representativo em Eisler: as obras que continham as tentativas de avanço quanto ao tratamento formal e do material musical, as obras onde podemos encontrar uma maior interação com o contexto político-ideológico de esquerda ou aquelas esteticamente convencionais e retrógradas, compostas em favor da construção do socialismo na RDA? Afinal, sobre este último tópico, a música que Eisler escreveu que, de longe, maior número de execuções receberia, teria sido o Hino da República Democrática Alemã (Nationalhymne der DDR), de 1949. Basta lembrarmos os jogos olímpicos dos quais este país participou até a queda do Muro de Berlim, transmitidos pela televisão via satélite para quase todos os países.

Pudemos nos aprofundar nestas questões a partir de nossa estada em Berlim. Lá tivemos a oportunidade de desenvolver pesquisas junto ao Arquivo Hanns Eisler e à Universidade Humboldt (Staatsbibliotek), quando realizamos o levantamento bibliográfico e pudemos debater com nosso orientador de então, Prof. Günter Mayer, renomado especialista e revisor da Obra Completa (Gesammelte Werke) de Eisler, questões pertinentes à sua vida e obra.

Quando voltamos para o Brasil, já nos parecia claro que as obras de Eisler, compostas em sua última fase na RDA, com raras exceções, não se confirmavam como exemplos bem-sucedidos quanto à qualidade artística. $O$ Eisler que nos interessava, acima de tudo, era o de uma estética musical moderna. Os aspectos mais decisivos para nossa avaliação corresponderiam à sua capacidade de compositor, sua maestria no desenvolvimento do material musical e sua ousadia estética para construção de uma obra que contivesse inovações formais.

Nosso objetivo principal agora seria atribuir a Eisler uma importância que lhe fosse realmente devida. Afinal, ele também seria um dos pilares da música moderna. Eisler poderia ser comparado a Villa-Lobos, por exemplo, pela produção musical heterogênea, na qual inúmeras obras-primas sobressaem a outros tantos trabalhos de valor acentuadamente menor. E, no caso de 
Eisler, a divulgação de sua obra acabaria sofrendo ainda com um empecilho grave: o preconceito ideológico. O posicionamento exclusivamente político, como ponto de referência à leitura crítica qualitativa, poderia confundir e não raro inviabilizar uma análise objetiva da música de Eisler, que, por causa disto, ora seria superestimada, ora subestimada.

Mas mesmo sendo justificado o estudo de sua obra independente do contexto político-ideológico, ele sempre serviria também para os compositores de hoje e das futuras gerações como exemplo da manifestação em obra musical do inconformismo diante da injustiça social. Mesmo porque "a crise do socialismo não tornou melhor o capitalismo"7, que por sua vez, "não apresenta soluções para os principais problemas do mundo"8.

Seria hora, portanto, de prosseguirmos no estudo sobre Eisler, na tentativa de compreendê-lo melhor. Com a comemoração de seu centenário - ao lado de Brecht, no próximo ano — , temos um bom motivo para refletir sobre estas questões...

\section{A Questão do Formalismo}

A forma, na música moderna, em seu aspecto estético essencialmente mais avançado, tem como base uma nova filosofia do compor, cuja referência principal é o tempo. Neste caso, a revolução da concepção temporal influenciou a busca de novos materiais musicais, pois, a partir destas novas atmosferas temporais, surgiriam inovações no campo das intensidades e dos timbres. A forma estaria assim determinando o conteúdo. Por outro lado, o inverso deste raciocínio também não seria equivocado, pois na modernidade musical, a revolução da concepção temporal (forma) ocorreria simultaneamente às inovações dos materiais musicais (conteúdo). Seria muito difícil precisar isoladamente o início deste processo.

Mas, de fato, esta nova plasticidade temporal, como capacidade de organização espacial dos materiais musicais, representaria o componente responsável pela geração de novas 
formas, que, por sua vez, impulsionaria também uma série de transformações nos materiais musicais.

Essa nova concepção formal seria o componente-chave que abriria as portas para a música de nosso tempo e permaneceria ainda hoje como importante objeto de estudo e discussão no campo da música contemporânea. Neste sentido, Webern teria sido o compositor mais avançado de sua época e exerceria ainda uma forte influência sobre a composição musical — via Darmstadt durante boa parte do período após a $2^{\mathrm{a}}$ Guerra Mundial.

No entanto, durante o transcorrer do século XX, mais polêmico que o conceito de forma, de um certo modo, foi o conceito de formalismo na arte, apesar de que, sem o reconhecimento da importância da funcionalidade formal, não poderiam ser desenvolvidas discussões objetivas sobre este assunto. E assim aconteceu: a discussão em torno do formalismo, mesmo que em alguns casos desprovida de fundamentação científica, ganharia uma importância histórica considerável.

Esta discussão não alcançou uma dimensão mais efetiva e producente, assim como não se desenvolveu no sentido do debate sobre o mérito da composição musical na modemidade — dando o exemplo de Webern, com uma nova concepção temporal da forma. A polêmica, de fato, que nos propomos a analisar, limitou-se ao debate sobre a seleção de materiais musicais, sobre os velhos e os novos conteúdos.

Sobre o conceito de formalismo, reconheceríamos duas interpretações possíveis: a primeira, concebendo-o pelas qualidades estéticas progressistas; e a segunda, criticando-o sob o ponto de vista da relação funcional estético-ideológica.

Como um dos exemplos da primeira interpretação, teríamos o movimento literário do formalismo russo, como crítica à arte acadêmica ou tradicional, preconizando a análise através de uma perspectiva formal. Neste sentido, o uso do adjetivo "formalista" seria dispensável. Bastaria atribuirmos à função da forma na obra de arte uma importância essencial.

Como exemplo da segunda, teríamos as críticas provenientes dos movimentos, no âmbito artístico, influenciados pela filosofia 
marxista-leninista. Nesta interpretação, destacaríamos pelo menos duas posições críticas mas essencialmente distintas quanto ao formalismo na arte: a jdanovista ou maniqueísta, que se deteve na defesa de velhos conteúdos, e a brechtiana ou dialética, que procurou identificar dialeticamente o papel revolucionário da forma. Trataremos a seguir, de uma melhor identificação de ambas, a partir de dados históricos.

\section{Reações ao Conceito Formalista de Jdanov}

Pretendemos estudar o debate em torno do formalismo a partir do discurso de Jdanov, com a leitura dos posicionamentos de Brecht e de Eisler, e, neste último caso, comparando sua postura antes e depois de Jdanov.

Esta análise visa a uma melhor compreensão das adversidades que não só Eisler mas boa parte dos compositores residentes nos países do bloco soviético enfrentaram a partir das conseqüências do discurso de Jdanov, que determinaria as diretrizes gerais e a linha dominante da histórica Conferência dos Representantes da Música Soviética junto ao Comitê Central do Partido Comunista da URSS, em Moscou, janeiro de 1948. "Mesmo os músicos progressistas de convicção socialista não foram compreendidos naqueles anos em suas próprias áreas de atuação, encontrando grandes dificuldades em superar conflitos"

\section{Discurso de Jdanov}

A política cultural na União Soviética durante a época de Stálin foi autoritária e centralizadora. Até mesmo decisões sobre questões artísticas ou estéticas vinham também do Politiburo do Comitê Central do Partido Comunista. E Andrei Alexandrovitch Jdanov, membro do Politiburo desde 1939, era o porta-voz desta cúpula composta por poucos, onde, fora o próprio Stálin, se destacariam então G. M. Malienkov, Molotov e, em especial, L. P. Beria - que viria a ser condenado por traição e fuzilado em dezembro de 1953, após a morte de Stálin. 
A partir do discurso de Jdanov ${ }^{10}$, acentuar-se-ia ainda mais a tendência Stálinista, cujo conteúdo seria definido por uma estética nacionalista e antimoderna, que já vinha sendo imposta para a política oficial da cultura musical desde os anos 30 , sob a forma de um maniqueísmo estético-ideológico, portanto, em nada dialético, resumido na "luta contra o formalismo" - o "inimigo do povo" e pelo "realismo" na música.

Independentemente do mérito das teses defendidas por Jdanov, seus argumentos estavam desprovidos de cientificismo e se mostravam dogmáticos. Se esse discurso fosse apenas mais um mal-aventurado artigo de jornal, ou uma crítica de qualquer revista musical, certamente passaria despercebido pela história da música. Mas, de fato, impunha-se como determinação oficial, tendo portanto de ser cumprido. Tratava-se de uma imposição estética que simplesmente definiria como os artistas deveriam trabalhar. E o governo em questão era o de Moscou, que indiretamente comandava também a política cultural em todos os países do bloco soviético.

$\mathrm{O}$ fato atingiria proporções gigantescas, se levarmos em consideração a importância e a influência direta que forçosamente exerceu no trabalho de milhares de compositores, entre os quais também se encontrava Eisler.

Ao criticar, por exemplo, a ópera $A$ grande amizade de Muradeli, Jdanov argumentara - subjetivamente - como problemática a falta de "uma melodia que se possa guardar", "a música não fala ao ouvinte", ou ainda que "não se pode substituir a riqueza melódica pelo improviso desarmônico e ao mesmo tempo muito barulhento". Jdanov acusara as intervenções orquestrais nesta ópera de "freqüentemente cacofônicas, desarmônicas e turbulentas" e, por isso, "irritavam os nervos do ouvinte, agindo agressivamente em sua alma".

Assim como Mário de Andrade, no Prefácio para um livro sobre Shostakovitch ${ }^{11}$, Jdanov também retoma a crítica do Pravda de janeiro de 1936, Caos em vez de música, contra a ópera Lady Macbeth de Mzensk de Shostakovitch. O compositor da Sétima Sinfonia, dedicada à cidade de Leningrado, era acusado desta vez, 
ao lado de Prokofiev, Katchaturian e Kabalevski, entre outros, de "figura central da linha formalista", e esta "linha", Jdanov considerava "errada". Ou seja, ele pretendia combater, a partir da URSS, toda e qualquer forma de influência da modernidade musical estrangeira e entendia que esses compositores estavam sendo influenciados principalmente pelo Ocidente.

Em resumo, para Jdanov, "realismo" era a "música nacional", a partir da tradição do séc. XIX, uma "ligação orgânica com o povo", o uso do material folclórico, a melodia, a "herança clássica", enfim, apenas uma visão conservadora da tradição.

E foi esse aviltado conceito jdanovista de "realismo socialista" que acabou caracterizando o termo, cujo significado sobrevive até hoje, digno de pilhéria, bem distante daquela arte capaz de integrar a vanguarda estética à vanguarda política. Em nenhum momento Jdanov entendeu por realismo aquele tipo de manifestação artística politicamente engajada e contestadora, como a produção de Brecht e Eisler dos anos 20 e 30.

"Formalismo", por sua vez, para Jdanov, era a "atonalidade", a "decadente música moderna burguesa", "cosmopolita" e "sem pátria", portanto "internacionalista", fruto dos "sentidos individualistas de um pequeno grupo de estetas elitistas".

O julgamento vinha de cima: "O povo não precisa de uma música que ele não entenda".

Havia em comum entre as políticas culturais de Hitler e Stálin, além da exigência de uma estética nacionalista, um combate oficial à modernidade. Na prática, a estética de Jdanov parecia-se muito com os resultados obtidos com a organização da política musical por Goebbels'2. O que era "música degenerada" para um, era "música formalista" para o outro. Assim como a música moderna era definida como "fruto do internacionalismo bolchevique, trabalho subversivo de todos os judeus"'13 pelos nazistas, os stalinistas a classificavam de "cosmopolitismo burguês".

Os argumentos dos nazistas eram os mesmos, quando o assunto era a atonalidade. Só trocavam o adjetivo "burguês" ou "cosmopolita" por "judeu". Alguns fascistas alemães tentariam até 
justificar sua aversão à modernidade através de conceitos supostamente etnomusicológicos: "Os atonalistas, os que fazem músicas com novos tons, que utilizam intervalos de quarto de tom, são judeus que obedecem a uma lei de sua raça, pois tentam destruir a polifonia harmônica, algo que lhes é estranho"14.

Parecia representar, tanto em Jdanov como nos nazistas, o gosto pelo nacionalismo, simultaneamente desenvolvido com a aversão à modernidade musical, uma relação de interdependência compatibilizada entre os dois aspectos. "Esta concepção nacionalista e neo-romântica da música harmonizava-se com o ideal imperialista do fascismo político: os militantes fascistas sonhavam disseminar, futuramente, os seus desejos e anseios revolucionários em todos os países do mundo". Esta idéia já vinha sendo desenvolvida desde as medidas político-culturais tomadas por Benito Mussolini na Itália nos anos 20 e 30, para a concretização de seu projeto musical ${ }^{15}$.

A luta por uma música de caráter nacionalista, em todo caso, não deixaria de ser mais compreensível pela influência da atmosfera de guerra daquela época. Mas este fenômeno se diferenciaria do surgimento das escolas nacionais no decorrer do séc. XIX, onde a busca da identidade musical de um país, ao contrário, estaria associada ao avanço do material musical como linguagem. Poderíamos observar isso em Chopin, Granados, Schumann e Fauré, entre outros. No séc. XX, haveria ainda os exemplos de Villa-Lobos (nos Choros, principalmente), Manuel de Falla e sobretudo de Béla Bartók, com a construção de uma linguagem musical de vanguarda a partir da música popular, porque, nestes casos, o material folclórico é trabalhado a partir dos meios e das técnicas de composição mais avançados.

A evolução da música ocidental, evidentemente, não teria sido e nunca poderia ser obtida por decreto. Ela seria sempre fruto da criatividade individual de poucos artistas. Apesar disso, não poderíamos desprezar a pesquisa musicológica, como um meio para a descoberta de outras causas desta evolução.

Mas, dando prosseguimento ao processo de implantação da luta contra o formalismo, de 20 a 29 de maio de 1948 - portanto, 
quatro meses após a Conferência Soviética com o discurso de Jdanov - teve lugar, em Praga, o II Congresso Internacional de Compositores e Críticos de Música, por ocasião do Festival de Música Primavera de Praga.

Eisler, recém-chegado do exílio norte-americano, foi um dos primeiros a falar entre os mais de 25 palestrantes, através de sua conferência Questões sociais fundamentais da música moderna ${ }^{16}$. Ele chamou a atenção para a crescente indústria cultural de entretenimento, que "faz da verdadeira arte uma arte de artigos" (que em alemão resulta em um trocadilho: Sie hat die wahre Kunst zur Ware Kunst gemacht) e, a partir da análise bipolarizada de Adorno - de sua Filosofia da música nova, mesmo que sem citálo diretamente - lembrou os defeitos e as virtudes das duas supostas linhas de composição mais influentes da modernidade musical: o neoclassicismo de Stravinski e a técnica dos doze tons de Schönberg. Eisler, pela sua própria ligação afetiva como aluno, identificou-se mais com este, muito embora a prática da composição musical, ao longo de sua carreira, tenha justamente oscilado entre a Escola de Schönberg e um tipo próprio de neoclassicismo.

Os fatos mais marcantes do Congresso, no entanto, aconteceriam durante os dois últimos dias, reservados às conferências da delegação soviética. Os três musicólogos russos, Chrenicov, Jarustovski e Chaporin, ditariam as linhas finais do encontro, ao explanarem sobre a estética jdanovista, restringindo a amplitude dos debates para a discussão em torno de sua luta contra o formalismo, que, a partir de então, passou a ser a tendência oficial dominante não só na URSS, mas também nos outros países do bloco.

De volta a Moscou, Jarustovski publicaria ainda um relatório sobre o Congresso, onde apareceria com destaque uma crítica direta a Eisler, por ele "ter defendido seu professor Schönberg, com argumentos não convincentes, apesar de sua palestra ter apresentado ao mesmo tempo idéias interessantes e progressistas"17. Já no relatório de Chrenicov, Eisler, ao lado de F. Poulenc, G. Auric e A. Bush, é acusado de "estar longe de se livrar da pressão das 
influências formalistas. Ainda é fortemente perceptível a inclinação modernista em sua música, expressa claramente através de uma desejada complicação da forma e da abstração da linguagem musical"18.

Eisler parece ter sido tomado de surpresa, não podendo imaginar, num primeiro instante, o grau de sectarismo que marcaria a política cultural, justamente naquelas sociedades que ele pretendia ajudar a construir.

A partir de então, sua obra seria subjugada pela linha oficial dominante. Poderia ele reagir contrariamente e se rebelar contra ela?

Haveria ainda, contudo, aqueles compositores, e dos bons, que iriam aderir à luta contra o formalismo por livre e espontânea vontade. Justamente pela defesa do nacionalismo e pela crítica à modernidade musical, caberia aqui, ainda mais uma vez, a curiosa comparação do discurso estético de Jdanov com a Carta aberta aos músicos e críticos do Brasil, publicada por Camargo Guarnieri em dezembro de 1950.

Uma das possíveis provas de que Camargo Guarnieri teria escrito sua Carta aberta a partir do discurso de Jdanov estaria na aplicação, em ambos os casos, da mesma citação integral da frase de Glinca, que já havia sido mencionada em parte também por Mário de Andrade, no seu Prefácio sobre Shostakovitch: "A música, criaa o povo, e nós, os artistas, somente a arranjamos"19.

O compositor paulista pretendia responder à crescente influência da Escola de Schönberg no Brasil, "aos avanços do chamado internacionalismo musical" 20 , que poderia ser sentido durante a década de 40 nas obras, entre outros, de Guerra-Peixe, Cláudio Santoro e Eunice Catunda. Em determinados momentos da carreira, nos anos seguintes, contraditoriamente, eles também se renderiam à mesma estética jdanovista, em conseqüência da militância destes três compositores nos movimentos de esquerda.

Não seria irrelevante lembrar que a relação de Jdanov com a música brasileira, por si só, já conteria material de estudo para muitas outras teses. Exemplos disso seriam também as observações 
de Gilberto Mendes sobre este aspecto histórico-ideológico da música brasileira: "A efervescência político-social daquele momento, somada a esses dois manifestos, de Jdanov e de Guarnieri, mais a coincidência entre pontos de vista de Jdanov e de Mário de Andrade, em seu famoso Ensaio sobre Mísica Brasileira, deram invulgar força à corrente nacionalista no Brasil. Indiscutíveis se tornaram, então, as palavras de Mário em seu Ensaio, sacralizadas, escritas uns 25 anos antes do discurso de Jdanov, o que lhe dava uma autoridade profética ... a obra não é brasileira, como é antinacional (escreveu sobre determinada música). E socialmente o autor dela deixa de nos interessar. Digo mais: por valiosa que a obra seja, devemos repudiá-la, como fez a Rússia com Stravinski e com Kandinski. O critério histórico atual da Música Brasileira é o da sua manifestação musical que, sendo feita por brasileiro ou individuo naturalizado, reflete as características musicais da raça. Onde estão elas? na música popular... Eram estranhas essas palavras, partindo de um autêntico intelectual de vanguarda, de um dos pilares da literatura moderna brasileira"21.

Assim como Mário de Andrade, Villa-Lobos, através de seu Canto Orfeônico - a partir de um ponto de vista estético - também teria sido jdanovista, antes mesmo de Jdanov. Neste caso, não por intermédio do Stalinismo, mas sim via fascismo italiano e alemão.

Ainda sobre Guarnieri, seria interessante observar como ele reagiria rapidamente ao discurso contra o formalismo. A publicação da Carta aberta é um ano anterior às primeiras manifestações oficiais de apoio à luta contra o formalismo na própria RDA, que datam de março de 1951, com o V Congresso do Partido Socialista Unificado da Alemanha (SED), a partir das resoluções contidas no documento A luta contra o formalismo na artes e literatura, por uma arte alemã progressista ${ }^{22} \mathrm{e}$ com a Introdução ao primeiro número da revista Música e Sociedade (Musik und Gesellschaft), escrita por Ernst H. Mayer ${ }^{23}$.

Essa arbitrariedade estética, que teria sido o jdanovismo, paulatinamente iria deixar de ser a política oficial para a cultura musical nos países do bloco soviético, principalmente a partir dos 
primeiros anos do governo de Nikita Kruchov, com as revisões do Comitê Central do Partido Comunista da URSS, publicadas na revista Música Soviética em maio de $1958^{24}$.

A oposição oficial à música moderna, contudo, duraria ainda até os primeiros anos da década de $70^{25}$. Mais acentuadamente entre 1948 (discurso de Jdanov) e 1958 (início do processo de revisão), uma oposição declarada à política oficial da luta contra o formalismo poderia acarretar em punições severas.

\section{Posicionamento de Brecht}

Bertolt Brecht, com receio disto - e até mesmo ele, nada publicou contrário ao discurso de Jdanov. Ele manifestaria suas opiniões num texto escrito em 1953, que só seria publicado dez anos após sua morte, portanto, em 1966. É através desta publicação ${ }^{26}$ que podemos tomar conhecimento de suas posições naqueles anos.

Para Brecht, a discussão em torno do formalismo tornava-se dificil, pois as pessoas erradas - como Jdanov ou E. H. Meyer estavam do lado certo e as teses certas recebiam a argumentação errada. $O$ que poderia ser uma tese certa sobre a luta contra 0 formalismo para Brecht, seria a crítica conseqüente "à desfiguração ou deturpação da verdade em nome da forma ou à provação dos impulsos pretendidos em obras de arte para com os anseios sociais". Trata-se, portanto, de uma crítica à filosofia de l'art pour l'art, caracterizada quando a autonomia do material artístico é reconhecida como absoluta, o que no conceito brechtiano - a partir de Hegel e Marx - só poderia ser concebida como relativa, dada a sua inevitável contextualização sócio-política, configurando a relação dialética entre estética e ideologia.

Outra tese correta para Brecht, em relação à crítica ao formalismo, já fora do âmbito artístico, seria o oportunismo aventureiro de alguns, principalmente na política, quando denominam novo, apenas por alterações de fachada - formais, por assim dizer, fatos que, quanto ao conteúdo, já eram velhos. 
Ou, para Brecht, o exemplo "mais terrível" entre todos os formalismos: "O socialismo dos nazistas." A forma era a de uma comunidade entre empresários e trabalhadores, viabilizada pelo "milagre econômico," através da política armamentista de Hitler. "No papel o povo tinha um Volkswagen, mas na dura realidade tornou-se um tanque".

Neste sentido, poderíamos efetuar a comparação entre Jdanov e Goebbels, que atuaram supostamente sob estruturas formais distintas, mas a partir do mesmo conteúdo, ou vice-versa. Este seria o formalismo entendido como um oportunismo de ordem política, que Brecht pretendia criticar, e, para isto, cita ainda uma série de outros exemplos da história alemã.

No mesmo sentido, Eisler, quando expulso dos EUA, acusaria o formalismo de seus inquisidores - e ele era o primeiro da "lista negra", pelo Comitê de Investigação de Atividades Antiamericanas: "Eu ouvia as perguntas desses homens e olhava os seus rostos. Como velho antifascista as coisas ficaram claras para mim, pois eles representavam o fascismo na sua forma mais direta"27.

Esse conceito de formalismo, para Brecht, seria então definível como a tentativa de sobrepor a aparência à essência, ocultando-a, ou seja, uma camuflagem de velhos conteúdos sob uma suposta nova forma.

A forma e o conteúdo estariam diretamente relacionados para Brecht, assim como já observamos nas considerações filosóficas do início deste capítulo: "A forma pertence ao conteúdo". "A forma de uma obra de arte não é nada além da completa organização de seu conteúdo, sendo o valor dela totalmente dependente deste". O nível da discussão, já com Jdanov, caiu para a esfera da crítica ao formalismo, como crítica às novas formas, sem as quais, para Brecht, a "arte não é arte", afinal, "na arte, conhecimento e fantasia não são opostos incompatíveis" 28 . Brecht defende a forma como importante componente da criação artística: "A forma representa um papel fundamental na arte". Embora "ela não seja tudo, tem grande importância, pois o desleixo para com a forma pode aniquilar uma obra". Brecht atribui uma importância decisiva às tentativas 
de inovação na arte através do aspecto formal: "Não teria o menor sentido ignorar a importância da forma e do desenvolvimento da forma na arte", assim como não se pode atingir novos públicos a partir de novas perspectivas de arte, "sem a introdução de inovações formais". É por isso que "construímos nossas casas assim como nossas peças diferentes dos Elisabethanos." Este exemplo demonstraria a incoerência do jdanovismo, quando, já em pleno séc. XX, continuaria insistindo na manutenção das formas e dos materiais musicais dos séculos anteriores, como se fosse possível coibir tal processo de desenvolvimento.

Respondendo diretamente aos jdanovistas, Brecht afirma que "eles nunca falam da atuação de uma obra de arte por si própria, mas sempre sobre seu respaldo popular. Eles mesmos não parecem pertencer ao povo. Mas, em contrapartida, sabem exatamente o que o povo quer e identificam o povo com isto, pois o povo quer o que eles querem. Eles dizem que o povo não entende. E o artista pergunta: você entendeu? Caso você não tenha entendido, diga tranqüilamente que você não entendeu," - o que seria muito mais sensato e produtivo - "e não que o povo não tenha entendido".

Definiríamos tais posturas como omissas, pelo nãoreconhecimento da própria ignorância ${ }^{29}$, ou mesmo como incomensuravelmente arrogantes ${ }^{30}$, pois generaliza-se como "gosto popular", uma convicção estética própria ou pessoal e, portanto, subjetiva. Sintetizando: "A ignorância é atrevida" (Nelson Rodrigues), "um indivíduo ignorante, revestido de autoridade, torna-se cruel" (Olivier Toni) e "o maior tipo de ódio que existe é o da ignorância contra o conhecimento" (Galileu Galilei). Devido a esse perfil de muitos políticos e administradores, a política cultural terá sempre seu desenvolvimento retardado, independentemente do país, do regime ou da época. Brecht concluiria ainda: "Na verdade, é um desaforo como essa gente subestima o povo, pela maneira depreciativa com a qual eles o avaliam."

O uso indiscriminado do adjetivo "cosmopolita", no seu sentido mais pejorativo seria mais uma prova do provincialismo com que Jdanov trabalha a questão. Brecht resume essa 
problemática em duas teses, pretendendo dar um ponto final na discussão: "1) As verdadeiras obras internacionais são as obras nacionais. 2) As verdadeiras obras nacionais acolhem em si as tendências e inovações internacionais" 31 .

Como brasileiros, compreenderíamos muito bem, principalmente a segunda tese, pois a música brasileira, erudita ou popular, sempre teria sido uma arte caracteristicamente conglomerativa, ou antropofágica, como diria Oswald de Andrade, pela reunião dos mais diversos materiais e técnicas - das mais variadas procedências - que resultariam sempre em uma nova unidade de um novo contexto.

Uma entre as inúmeras provas disso seria a obra pianística Um estudo? Eisler e Webern caminham nos mares do sul, de Gilberto Mendes $^{32}$. O compositor santista utiliza aqui elementos seriais, melódicos e harmônicos de Webern e Eisler numa fusão aclimatizada aos trópicos, adaptando-os fantasiosamente à sensação do vento e das ondas numa praia brasileira... uma obra nacional, a partir do expressionisíno alemão.

\section{Reação de Eisler ao Discurso de Jdanov}

Eisler talvez tenha sido mais corajoso que Brecht, ao publicar uma série de teses sobre a questão ainda em 1951, logo após a defesa das posições jdanovistas por E. H. Mayer em Berlim, na $\mathrm{RDA}^{33}$. Porém, o texto de Eisler ficaria aquém da dimensão estética e do desenvolvimento objetivo da análise de Brecht.

Eisler escreveu sob a forma de uma carta fictícia - Carta à Alemanha Ocidental ${ }^{34}$ - , como se ele desenvolvesse um diálogo com os compositores ocidentais, sobre o debate em torno do formalismo, mas já se colocando ao lado da defesa, em sua maior parte, das teses de Jdanov.

Ao contrário de Brecht, que discerniu muito mais os absurdos do que as virtudes da polêmica, Eisler tomaria para si a árdua incumbência de solidificar o conceito de realismo na música: "A música encontra-se hoje diante de uma tarefa singular e 
contraditória: ela precisa se tornar, de certo modo, sensata e realista, e contudo, permanecer música" e "nós compositores precisamos requerer dos ouvintes o mesmo realismo que nos é exigido".

Seria no mínimo constrangedor que um artista do porte de Eisler, polêmico, cuja obra se caracterizaria pelo rompimento de normas e que até então sempre teria estabelecido com grande desenvoltura o seu próprio caminho, viesse a se submeter de tal modo, aceitando uma imposição arbitrária que decidiria o rumo de sua própria estética. No entanto, ele permitiu que tais determinações, oriundas de políticos — não artistas - o influenciassem sobremaneira. Prova disso seriam as já mencionadas obras de sua última fase.

Caberia aqui a nossa pergunta inicial: Eisler, criador de uma obra moderna, original, diferenciadamente expressiva e ousada, a partir de um determinado ponto, regrediu sua linguagem musical, tornando-se um compositor conservador e obsoleto. Por quê?

A resposta estaria mesmo no fato de ter-se deixado levar pela estética jdanovista. Mas se foi por oportunismo, por concordância sincera e consciente ou se porque não teria mais ânimo, àquela altura, de continuar se desenvolvendo como compositor moderno, são perguntas que permanecerão sem respostas.

Eisler, assim como Brecht, nunca efetivou sua filiação ao Partido Comunista, embora fossem chamados de "companheiros" (Genossen) entre os militantes. Mas o Partido, a partir da questão jdanovista, passa a definir - através de sua crítica formalista — os rumos estéticos na obra de Eisler. Talvez possa ser, de fato, a força do poder. Tanto é que, durante a República de Weimar, as críticas de determinados setores do KPD (Partido Comunista Alemão) não teriam tido a mesma importância ou influência para o desenvolvimento de sua obra ${ }^{35}$.

$\mathrm{E}$, de fato, já nesta última fase, por conseqüência de uma tendência oficial, Eisler se afastaria da modernidade. Lembraríamos, neste sentido, as palavras de Brecht em A vida de Galileu Galilei: "A modernidade se identifica com o espírito da livre iniciativa e se choca sempre com o espírito doutrinário e com a defesa dos aparelhos de poder" 36 . 


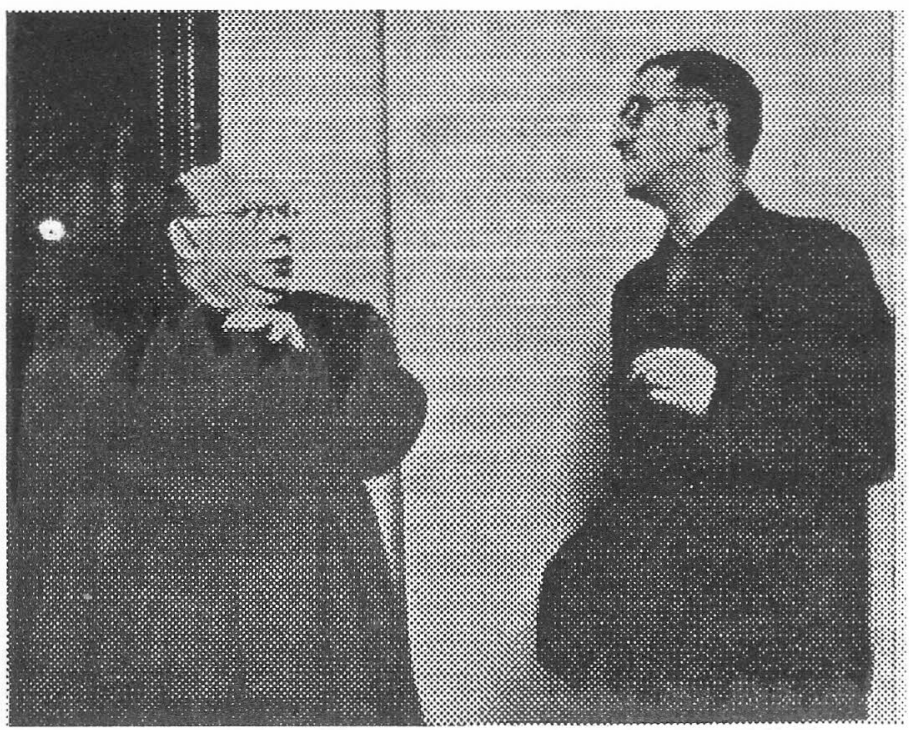

Eisler com Brecht em 1950

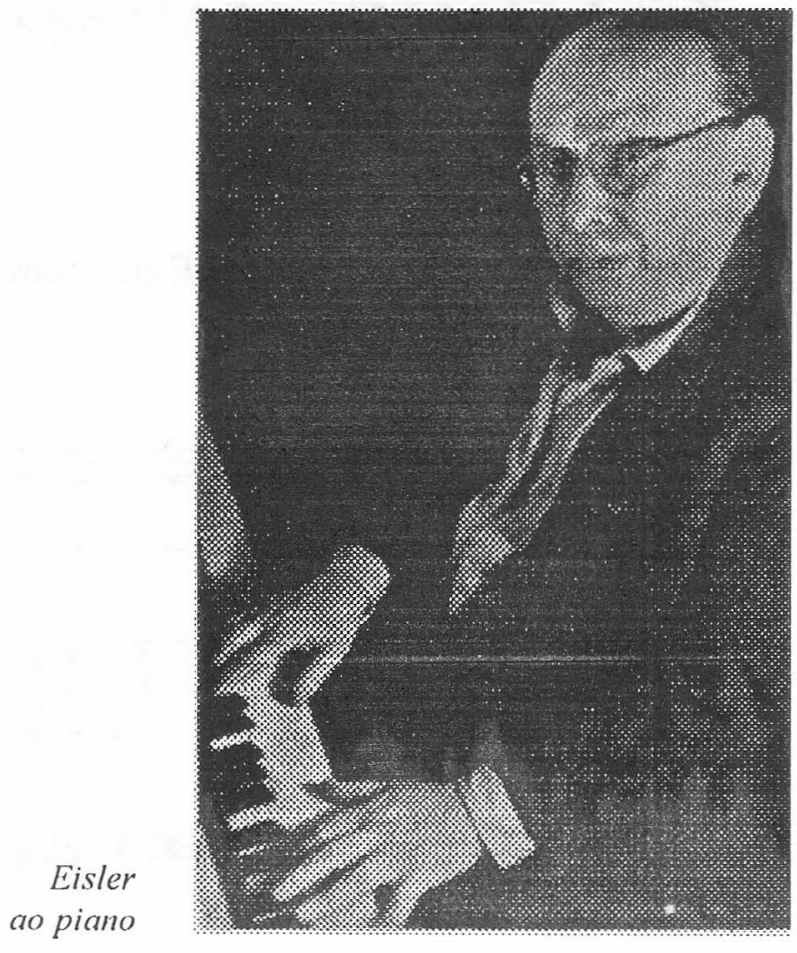


Poderíamos até comparar o repertório de hinos e marchas da fase jdanovista de Eisler às séries do Canto Orfeônico de VillaLobos, sob o ponto de vista do tratamento do material musical. Embora o texto em Eisler seja, por exemplo, sobre Lênin, e em Villa-Lobos, sobre Duque de Caxias, o estilo musical permanece o mesmo - como podemos observar nos exemplos musicais 1 e 2 - com a coincidência de frases igualmente convencionais e com a mesma harmonia tonal, simplória e inexpressiva.

Exemplo 1 - Cânone Duque de Caxias de H. Villa-Lobos.

Canto

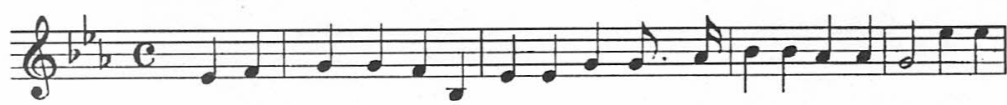

Sal-ve oh Du-que glo-ri - o-so Sal-ve oh!Ca - xi-as mui gen-til Sal-ve

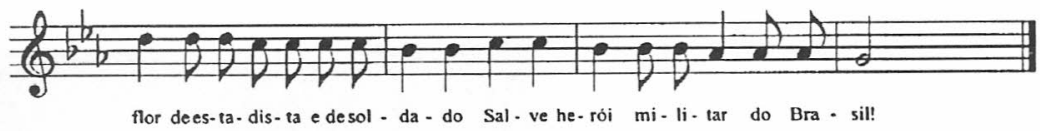

Exemplo 2 - Lênin de Hanns Eisler, com texto de Johannes R. Becher.
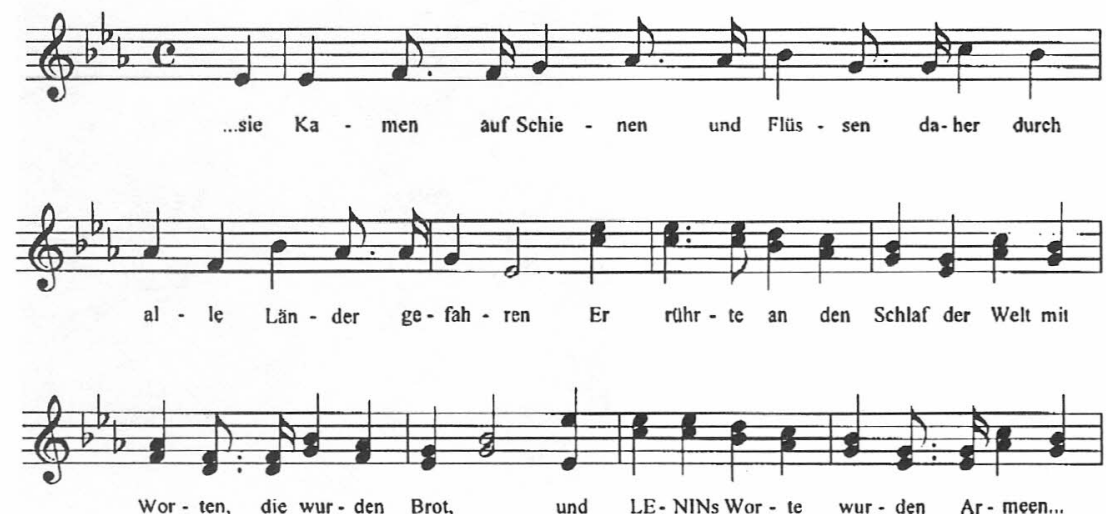
$O$ uso restrito de uma linguagem musical retrógrada e antiquada, como no caso destes repertórios de Eisler e Villa-Lobos, praticamente impossibilitaria uma melhor elaboração do material musical, ao ponto de transformá-lo numa obra musical de interesse artístico. O criticável em Eisler seria a sua pretensão de compor musicalmente um texto sobre Lênin, o "revolucionário", mas contraditoriamente, escrevendo, para isso, uma música "reacionária". Esses adjetivos estão aqui empregados, levado em conta o ponto de vista de Maiacovski, contida na frase que encerra o Monifesto Música Nova brasileiro: "sem forma revolucionária não há arte revolucionária" ${ }^{37}$. Trata-se de um raciocínio bem conhecido, já óbvio e ululante. E por isso mesmo, não podemos ignorá-lo.

Diante da pergunta se Eisler teria contribuído com suas obras da última fase para a edificação cultural de uma sociedade socialista na RDA, gostaríamos de citar aqui, mais uma vez, Heiner Müller: "O socialismo até hoje só existiu em nossas cabeças, não como sistema. O que houve, foi uma estrutura que talvez possa ser definida como um sistema de reduzida produção de artigos. Então o socialismo acabou? Não, não acabou. $\mathrm{O}$ que acabou foi a tentativa de refutar Marx. Há em Marx a frase simples: a experiência de se construir o socialismo ou uma estrutura socialista sobre a base de uma economia de penúria acaba na mesma velha porcaria de antes. E foi isso que nós acabamos de vivenciar agora" ${ }^{38}$.

Voltando à Carta à Alemanha Ocidental (Brief nach Westdeutschland), Eisler falaria ainda da necessidade "urgente de uma música que seja facilmente compreendida pelos ouvintes menos experientes" e após uma série de considerações sobre a dificuldade de se colocar a classe trabalhadora ao alcance da "grande herança da música clássica e moderna - seria mais fácil antes disto construir usinas atômicas ou ir à lua" - completaria ainda afirmando que "tais pessoas precisam de um novo conceito de popularidade". E sobre a questão da música popular, Eisler argumentaria vagamente que "tal pergunta só poderá ser respondida, de fato, com partituras musicais". Ele ainda acrescentaria, que "a nova popularidade é a transformação do novo para o simples". 
Os ideais do discurso verbal de Eisler, naquele momento, não seriam concretizados na prática. Seu discurso musical mostrara-se como uma estética desmedidamente estéril sob o ponto de vista da modernidade. Ele resolveria a questão, assim como no jdanovismo, subestimando o conceito de "popularidade", atribuindo-lhe o significado de uma arte de entretenimento fácil, convencional e pouco criativa - ao contrário do que ele talvez pretendesse. Eisler transformaria, na realidade, o novo no velho e simplório. De fato, sua tarefa talvez tenha-se tornado ainda mais dificil por ele ser um compositor da Alemanha - país cuja tradição de música popular já havia sido interrompida desde o séc. XIX e, sob este aspecto, ficaria em larga desvantagem em relação, por exemplo, aos seus contemporâneos brasileiros, que dispunham de uma música popular viva e rica.

Eisler leva a discussão para o lado de uma "crise na vida musical, caracterizada principalmente pela contradição entre o desenvolvimento da música de concerto - cada vez mais complicada - e o da música de entretenimento - de consumo fácil", e essa contradição teria ocasionado um "abismo" entre estas duas esferas musicais. Neste sentido, o compositor retoma a crítica à indústria cultural de entretenimento, também presente nas Questões sociais fundamentais da música.

Utilizando ironicamente uma frase usada por Adorno em sua Filosofia da música nova, Eisler atacaria a posição pomposa e bombástica de certos compositores da vanguarda estética - o que se configuraria então como formalismo musical a ser combatido - que, em atitudes isolacionistas, através da filosofia "l'art pour l'art, l'expérimentation pour l'expérimentation ou ainda la nouveauté pour la nouveauté", ignorariam o objetivo e a responsabilidade social da música, citando ainda como exemplo os pensamentos de Hegel contidos na Estética, uma obra de referência em vários momentos de sua vida ${ }^{39}$.

Tais críticas valeriam, se relacionadas com as obras politicamente engajadas de sua $3^{a}$ e $4^{a}$ fase, mas cairiam irremediavelmente no vazio em sua $5^{\text {a }}$ e última fase, já que sua 
produção de caráter jdanovista, desprovida de modernidade estética, não sobreviveria somente por apoiar-se em textos verbais que contivessem preocupações com o contexto político-ideológico.

O ponto musicologicamente mais consistente de toda Carta à Alemanha Ocidental é a crítica à obrigação do emprego da melodia na música da modernidade, tão exigida no discurso de Jdanov. Para Eisler, a "melodia não é um aspecto imanente da música, mas sim um fenômeno histórico". A melodia só seria compreendida a partir de Schubert, no início do séc. XIX, "quando o tema se tornou a melodia, a inspiração e com isso a propriedade privada, que precisa ser protegida" - já aqui ironicamente, caracterizando-a como um advento burguês - sendo que Haydn, Mozart e até Beethoven pensavam antes no desenvolvimento temático, como elaboração de uma idéia musical. No entanto, o repertório desenvolvido por Eisler a partir daí utilizaria insistentemente a melodia ainda como componente essencial da composição musical.

Seria interessante observar ainda outras incoerências em Eisler, também analisadas a partir das contradições entre o seu discurso sobre música e o seu discurso musical. Suas críticas ao neoclassicismo musical, por exemplo, também não seriam coerentes com sua obra. Eisler pretendia atacar - via Stravinski - o contexto ideológico desta linha. No entanto, os componentes estéticos do neoclassicismo seriam úteis para a edificação de sua obra mais politicamente engajada. Falta nos textos de Eisler, portanto, uma crítica mais diferenciada ao neoclassicismo.

Se, por um lado, ele procurou teoricamente elevar as idéias de Jdanov para um nível mais dialético, manteve-se, na prática, fiel aos princípios estéticos primordiais deste; e a produção musical em sua $5^{a}$ e última fase seria a maior prova disso.

Justificaríamos a análise da Carta à Alemanha Ocidental por sua importância histórica, como um documento que retrataria as reflexões e as atitudes de Eisler naquele momento de transformações, com a possibilidade de contribuir para o estabelecimento de uma cultura socialista e diante que estava do 
significativo debate estético-ideológico na luta contra o formalismo — independentemente do mérito — , que caracterizaria uma linha estética dominante e imposta pela força, como já vimos.

Mas este texto, apesar ainda de sua utilidade quanto ao esclarecimento de algumas questões fundamentais propostas no início deste artigo, não poderia ser considerado, quanto ao conteúdo — no sentido da representatividade do pensamento eisleriano como um todo - tão importante quanto outro texto seu, quando Eisler, ainda no exílio, havia tratado exatamente das mesmas questões, mas a partir de outras perspectivas.

\section{Eisler antes de Jdanov}

O texto Arte de vanguarda e frente popular ${ }^{40}$, de 1937, seria sim um bom exemplo da sintonia em Eisler entre seus mais significativos pensamentos teóricos e sua produção musical de maior interesse. Acima de tudo, trata-se de um Eisler antes de Jdanov, independente, ousado, original e que não media as palavras por receio de uma possível colisão com os aparelhos institucionalizados de poder.

Neste texto, Eisler falaria da relação entre a frente popular e a vanguarda musical, onde o termo "vanguarda" seria aqui empregado com boa dose de ineditismo: "A frente popular precisa dos artistas mais progressistas, porque não é suficiente, apenas, possuir a verdade. Ainda faz-se necessário conferir-lhe a expressão mais moderna, mais precisa e a mais brilhante." Observaríamos, já pela defesa da modernidade, uma contradição clara com suas posições pós-Jdanov.

Eisler, em a Arte de vanguarda e frente popular seria um idealista que sonhava com o "desaparecimento das diferenças entre as duas esferas na sociedade do futuro", e pretendia, como ação emergente, defender a vanguarda oprimida, "isolada das grandes massas e ameaçada de ser aniquilada pelos fascistas".

Ele não deixaria de reconhecer, contudo, os mesmos pontos polêmicos que estariam presentes no debate jdanovista, mas sob o 
mesmo ponto de vista de Brecht, ao apontar as fraquezas da vanguarda, "sua alienação e seus formalismos", conceito empregado aqui como crítica à l'art pour l'art, quando a autonomia do material musical é reconhecida como absoluta.

Provavelmente entusiasmado com as possibilidades reais do simultâneo avanço estético-ideológico, a partir dos resultados obtidos em sua 3 a. fase, o compositor atribuiria ao conceito de vanguarda uma nova dimensão: "O novo material precisa afirmarse hoje junto aos novos conteúdos e tornar-se útil para as tarefas sociais, pois o artista só será um vanguardista de fato, quando ele conseguir unir as duas vanguardas (ideológica e estética), defendendo e incentivando os interesses das massas através dos meios artísticos mais novos e ousados. A vanguarda não poderá ser mais conduzida como se ela fosse uma ilha isolada dos movimentos sociais".

Em Arte de vanguarda e frente popular, Eisler imaginaria, com a união das vanguardas na arte e na política, o fortalecimento da luta contra o fascismo, que, àquela altura, iniciava seu caminho irreversível para a $2^{a}$ Guerra Mundial. E não poderiamos deixar de reconhecer a originalidade e o valor desta abstração insigne, independentemente de sua efetividade.

\section{Apêndice}

Poderíamos estabelecer as seguintes fases na obra de Eisler:

\section{$1^{\text {a }}$ Fase (Viena, até 1923) - Obras de Juventude}

São as primeiras tentativas de composição de Eisler. Caracteriza-se por uma linguagem tonal do romantismo tardio. Destacam-se as Cinco peças para piano, Três canções para orquestra - com textos de Li Tai-Pe e Klabund - e uma série de canções para canto e piano.

$2^{\text {a }}$ Fase (Viena, 1923-1925) - Escola de Viena de Schönberg São as obras compostas imediatamente após os quatro anos 
consecutivos de aulas com Schönberg (1919-1923). Embora Eisler tenha sido aluno também de Webern, sua linha de composição principalmente na concepção temporal da forma - é de fato mais próxima ao próprio Schönberg. Caracteriza-se pelo atonalismo livre ou já pelo uso de técnicas seriais. Destacam-se as Sonata $N^{\circ}$. I Op. I (1923) e a Sonata $N^{o} 2$ Op. 6 (1924) para piano, as Seis canções para canto e piano Op. 2 (1922-23), o Divertimento para quinteto de sopros Op. 4 (1923), Palmström Op. 5 (1924) paródia do Pierrot Lumaire, Duo para Violino e Violoncelo Op. 7 (1924), as Quatro peças Op. 3 (1923) e as Oito peças Op. 8 (1925) para piano.

\section{Obras de Transição}

Da fase schönbergiana para o neoclassicismo engajado, Eisler compõe quatro obras satíricas. A cantata Tagebuch Op. 9 (1926), as canções dos Recortes de Jornal Op. 11 (1925-27) - obrasprimas da modernidade musical - e duas obras corais: as Três peças para coro masculino Op. 10 (1925) e as Quatro peças para coro misto $O p .13$ (1928-29). As duas primeiras estão, estilisticamente, ainda mais inseridas na $2^{a}$ fase e as duas últimas, na $3^{a}$ fase.

$3^{\mathrm{a}}$ Fase (Berlim, 1926-1933) - Neoclassicismo politicamente engajado

Na sua maior parte, são obras engajadas nos movimentos político-artísticos de esquerda. Caracteriza-se pela retomada do sistema tonal e pelo emprego do desenvolvimento temático como configuração formal. São desta fase suas melhores canções de luta. A partir daí, tem início o seu trabalho como compositor de cinema e teatro, desempenhado até o final de sua vida. O trabalho conjunto com Bertolt Brecht torna-se uma importante referência. Destacamse as obras: as cantatas Tempo der Zeit Op. 16 (1929) e $A$ mãe Op. 25 (1931). As peças corais Para cantar na rua Op. 15 (1928) para coro misto, Dois Corais Masculinos Op. 17 (1929), Duas peças Op. 19 (1929) para coro masculino e as Duas peças para 
coro masculino Op. 21 (1930). As peças para canto e piano Seis baladas Op. 18 (1929-30), Quatro baladas Op. 22 (1930), a Balada do Soldado Op. 39 (1928) com texto de Brecht, Seis Canções Op. 28 (1929-31) e as Quatro Canções para uma mãe operária Op. 33 (1932). Suas peças para piano Dezoito pequenas peças para piano Op. 31 (1932) e as Sete peças para piano Op. 32 (1932). Inúmeras composições para teatro, como A medida Op. 20 (1930) e para cinema, que depois foram transformadas em suítes para orquestra, como a Suite $N^{o} 2$ Terra de ninguém Op. 24 (1931), Suite $N^{o} 3$ Kuhle Wampe Op. 26 (1931-32) e a Suite $N^{o} 4$ A juventude tem a palavra Op. 30 (1932). Paralelamente, Eisler continua compondo obras seriais. Exemplo disso é a Pequena Sinfonia Op. 29 (1932), esteticamente ainda ligada à sua $2^{\mathrm{a}}$ fase.

\section{$4^{a}$ Fase (Exílio, 1933-1948) - Entre o Neoclassicismo e a Escola de Schönberg}

Eisler permanece vários anos sem residência fixa, passando por vários países da Europa e pelo México, até se estabelecer nos Estados Unidos, em 1938. Nesta fase, retoma a linha da Escola de Schönberg em algumas obras, prossegue no desenvolvimento de sua tendência neoclássica em outras, assim como através da composição de canções, redescobre a tradição do Lied alemão. É desta fase, a maior parte de sua produção camerística, ora ligada à Escola de Schönberg, onde freqüentemente utiliza-se de técnicas seriais, ora com o emprego de formas neoclássicas. Destacamos: Prelúdio e Fuga sobre B-A-C-H Op. 46 (1934), Sonata para flauta, oboé e arpa Op. 49 (1935), Sonata para violino e piano - Sonata Viagem (1937), Quarteto de cordas (1938), Noneto $N^{o} 1$ (1939), Septeto $N^{o} 1$-Variações sobre canções infantis do folclore norteamericano Op. 92 (1940), Noneto $N^{\circ} 2$ (1941), Quatorze maneiras de descrever a chwva Op. 70 (1941), Sonata para piano $N^{o} 3$ (1943) e o Septeto $N^{o} 2$ - O circo (1947). Um destaque especial merecem ainda os ciclos de canções, como as Elegias de Hollywood (1942) - além de inúmeras outras canções com textos de Brecht - e os Fragmentos de Hölderlin (1943). Por causa destas obras, Eisler se 
confirma como um compositor de Lied de grande importância no séc. XX. Destacam-se também as séries de cantatas de câmara escritas em 1937 e as obras sinfônicas Sinfonia Alemã Op. 50 (193559) - sua maior obra, as Cinco peças para orquestra (1938-40) e a Sinfonia de Câmara Op. 69 (1940).

5 Fase (Berlim, RDA, 1949-1962) - Fase jdanovista

A maior parte das obras desta fase são compostas diretamente sob influência do discurso de Jdanov. Caracterizam-se pelo uso simplório do sistema tonal e pelo reemprego das formas mais tradicionais de hinos e canções populares alemãs, sobretudo do séc. XIX. Como exemplo, temos: Rapsódia de Goethe (1949), Hino da Repuiblica Democrática Alemã (1949), Novas canções populares alemãs (1950), as cantatas Meio do Século (1950), Das Vorbild (1951-52), Os tapeceiros de Kujan-Bulak (1957) e os Quadros de uma Cartilha de Guerra (1957). Destacariamos suas Canções Infantis com textos de Brecht (1950-51) assim como A canção distante - que faz parte das Novas canções populares alemãs, como obras mais bem-sucedidas ainda que dentro da linha jdanovista. E ainda a cantata Lenda do surgimento do livro Taoteking no caminho de Laotse para a imigração (1957), retomando o estilo de suas cantatas de exílio, as satíricas Canções com textos de Kurt Tucholsky (1959-61), retomando o estilo de suas canções políticas dos anos 20, antes do trabalho conjunto com Brecht e os Cantos Sérios (1961-62), sua última obra. Eisler, aqui, apresenta em versão unitária, para barítono e orquestra de cordas, uma coletânea de canções, algumas novas, outras de fases anteriores, como as extraídas do ciclo Fragmentos de Hölderlin, como se ele pretendesse, já ciente da morte próxima, refletir retrospectivamente sobre sua própria vida e obra. 


\section{NOTAS}

1. O Festival Internacional Música Nova completa, em 1998, sua trigésima quarta edição, homenageando o centenário de Brecht e Eisler. É um dos poucos eventos do gênero no Brasil que divulga a obra de Eisler. Exemplos recentes disto são: o Festival de 1991, quando foram apresentadas 17 canções de Eisler, no recital Das ferne Lied, com o tenor berlinense Peter Siche; o Festival de 1992, com a apresentação pelos pianistas Antônio Eduardo e Rubens Ricciardi da abertura da cantata A Mãe; o Festival de 1993, com a execução do Prelúdio e Fuga sobre B-A-C-H e do Duo para violino e violoncelo, pelo Ensemble Mentemanuque de Ribeirão Preto; e em 1994, com as apresentações do Divertimento para quinteto de sopros, pelo Ensemble Arcane da Bélgica e das Sete peças para piano, pelo pianista Antônio Paulo Russomanno Veiga. Para o ano de 1998 está programada uma série de eventos para comemorar o centenário de Eisler, com concertos - como um recital de canções com o soprano Andrea Kaiser, sob direção cênica de Fernando Peixoto - e palestras, com a vinda do grande musicólogo alemão Albrecht Dümling.

2. A bibliografia existente no Brasil sobre Eisler ainda é pequena. Há livros traduzidos sobre a música no século XX que nem sequer mencionam Eisler, mesmo quando o assunto envolve diretamente a Escola de Viena de Schönberg. Exemplos disso seriam Para compreender as músicas de hoje e Schönberg, dos autores franceses H. Barraud e R. Leibowitz, respectivamente. Em A Música Moderna, nas páginas 113 e 114, o inglês Paul Griffiths fala sobre Eisler sem nenhum aprofundamento, como "músico de maior engajamento na República de Weimar, que se tornou o mais íntimo e fiel colaborador de Brecht". Em poucas linhas, Griffiths fala da controvérsia com Schönberg, que "deplorou sua filiação a um partido" o que nem corresponderia exatamente à verdade. Primeiro, não há documentos que comprovem uma possível filiação de Eisler a um partido, nem mesmo ao Partido Comunista. Segundo, Schönberg não atribuía muita importância às tendências ideológicas de Eisler, considerando-as superficiais e passageiras. A divergência se deu sobretudo no âmbito estético: Schönberg ficou desapontado com a insatisfação de Eisler, expressa naquele instante, para com a música moderna e a técnica dos doze tons. Griffiths ainda cita Eisler numa lista conjunta com vários outros compositores que deixaram a Europa por causa do nazismo. Nesta mesma lista de exilados de Hitler, com algumas alterações em relação aos nomes de outros compositores, Eisler também aparece na História Universal da Música, do francês Roland de Candé, na pág. 270. Afora isso, mais adiante, na pág. 334, Eisler é apenas lembrado como um aluno de Schönberg, compositor de "admiráveis trilhas sonoras em escrita serial" (em particu- 
lar A Chuva de Joris Ivens). No livro Música da Modernidade, do brasileiro J.J. de Moraes, Eisler não chega a merecer um capítulo próprio, sendo apenas citado numa generalização, juntamente com Prokofiev e Weil, devido a aspectos políticos. Só mais recentemente começa a surgir o interesse sobre a obra de Eisler por parte de outros autores brasileiros. Prova disto é o livro Uma odisséia musical — dos mares do sul à elegância pop/art déco de Gilberto Mendes, onde, pela primeira vez em nosso país, Eisler acaba por roceber uma importância mais especial no panorama da música modena.

3. Heiner MÜLLER, in: Der Spiegel, primeira semana de agosto de 1990.

4. O que J. J. de Moraes afirma, acerca do neoclassicismo em Villa-Lobos nos anos 30, valeria também, de um certo modo, para a produção de Eisler do mesmo período: "Villa-Lobos, segundo suas próprias palavras, pretendeu com essas obras (no caso, trata-se das Bachianas) unir a linguagem de J. S. Bach — que tomava como uma espécie de catalisação do folclore universal 'vindo do astral' imponderável - a elementos dos vários folclores brasileiros". Eisler, por sua vez, teria aproveitado diretamente a popularidade do velho mestre na Alemanha para a eficiência política de suas obras, que obteriam assim uma melhor penetração junto ao movimento operário. J. J. de Moraes concluiria ainda que "hoje, entretanto, já é possível afirmar que Villa-Lobos, antes de mais nada, seguia o movimento geral de certa faixa da produção musical européia, o neoclassicismo, tendência que buscava recuperar a dignidade de tudo aquilo que tinha um certo aspecto antigo". Cfr. J. J. MORAES, Música da Modernidade, São Paulo, Brasiliense, 1983, p. 174.

5. Exemplo desse repertório de caráter popular-revolucionário são as canções de luta, como $O$ Wedding vermelho (Der rote Wedding), $O$ desfile pátrio (Der heimliche Aufmarsch), A canção da solidariedade (Solidaritätslied), A canção da frente única (Einheitsfrontlied) e $A$ balada dos Säckeschmeissern (Ballade von den Säckeschmeissern), cujo tex= to é sobre a crise financeira de $1929 \mathrm{em}$ Nova Iorque e sua conseqüência para o Brasil, com a destruição da produção de café, especificamente na região de Ribeirão Preto, então maior centro produtor de café do mundo - No Brasil junto ao Rio Grande (In Brasilien am Rio Grande).

6. As novas canções populares alemãs (Neue Deutsche Volkslieder) e a cantata Meio do Século (Mitte des Jahrhunderts) teriam sido compostas por Eisler sob pressão de Johannes R. Becher, autor dos textos, que então era Ministro da Cultura da RDA.

7. Heiner MÜLLER, op. cit.

8. Wolfgang HERBERT, in: Carta a Rubens Ricciardi, Uffenheim, 23.2.90.

9. Cfr. Günter MAYER, "Revolução na música - As vanguardas de 1200 e 2000", in: Revista Música, São Paulo, Departamento de Música da ECAUSP, 1(1):15, 1990. 
10. A. A. JDANOV (na grafia alemã SHDANOW), "Eröffnungsrede auf der Beratung von Vertretern der sowjetischen Musik im ZK der KPdSU" e "Fragen der Sowjetischen Musikkultur - Moskau, Januar 1948", in: Über Kunst und Gesellschaft, Berlim, Dietz, 1951, p. 46-79.

11. Seriam evidentes as inúmeras coincidências quanto ao conteúdo de antimodernidade e à tendência para o estabelecimento estético do elemento popular entre o discurso de Jdanov e o Prefácio de Mário de Andrade para um livro sobre Shostakovitch. Observaríamos ainda, que o texto do autor brasileiro (janeiro de 1945) é três anos anterior ao russo (janeiro de 1948). Teria tido Jdanov algum conhecimento sobre Mário de Andrade? Ele resume: "Na urgência de criar uma música que fosse política, comunista e proletária, porém que conservasse o nível da música erudita, de base fatalmente burguês-européia, nẹ sempre as soluções adotadas por Chostacovich foram satisfatórias. Si ele aceitou com lealdade os clementos musicais demagógicos, nem sempre suas demagogias sonoras levam à virtude, mas ao vício". (A "demagogia" para Mário de Andrade era, por exemplo, em Shostakovitch, o uso de finais de um triunfalismo populista, que de l:ma certa maneira, até ele mesmo defendia Chostacovich havia de aceitar conscientemente elementos ditos 'demagógicos' pela efeminada epiderme burguesa). Si aceitou com franqueza a liderança melódica e suas consequiências estratégicas de espírito, de estilo e de técnica, nem sempre ele soube se conservar dentro da pureza melódica e da necessária facilidade do acessivel. Seriam ainda surpreendentes os posicionamentos extremados de Mário de Andrade - justamente o grande autor da modernidade brasileira - contra alguns aspectos técnicos da música moderna, via stalinismo: "Não só se impurificou por demais nos cromatismos, não sabendo como, ou não podendo ultrapassar a deliqüescência burguês-capitalista do ultratonalismo..." Mário de Andrade já teria da mesma maneira reconhecido, e antes de Jdanov, "como justa a denúncia do Pravda, e necessária a punição de Chostacovich". Cfr. Mário de ANDRADE, "Prefácio", in: Victor SEROFF, Shostakovich, São Paulo, 1945, p. 20, 23 e 27.

12. Seria pertinente lembrarmos, sobre esta questão, a opinião de Cornelius Cardew, compositor inglês e aluno de Stockhausen, que rompeu com a linha de composição deste, partindo para a difusão de uma música politicamente engajada, quer seja como compositor ou organizador de eventos musicais (Strach Orchestra), tendo como referência a Revolução Cultural na China de Mao Tse Tung. Cardew procurou diferenciar, a partir das perspectivas da luta de classes, a oposição nazista à arte dita "degenerada": "A campanha nazista contra a arte 'degenerada' é avaliada diversamente por classes diversas. Para a burguesia, as vítimas maiores desta campanha foram os vanguardistas burgueses: Klee, Kandinski, Schönberg 
e outros, cujo trabalho refletia a degeneração metafísica da burguesia. Do ponto de vista proletário, as vítimas principais foram os artistas comunistas da República de Weimar: Georg Grosz, Käthe Kolwitz, Hanns Eisler e Bertolt Brecht". In: Cornelius CARDEW, Stockhausen al servizio dell'imperialismo, Milano, Edizione di Cultura Popolare, 1976, p. 102. Não seria fácil concordar inteiramente com tal afirmação, mesmo quando nos limitamos à compreensão do fato através de uma perspectiva política, pois a atribuição de um gosto artístico a individuos, exclusivamente de acordo com á classe social a que pertencem, não deixa de ser uma posição dogmática e desprovida de cientificismo.

Lembraríamos aqui, que a maioria destes artistas era de origem judaica e obras de artistas judeus eram proibidas na Alemanha nazista, independentemente da estética, como Mendelssohn, por exemplo, tão romântico e alemão como Schumann. A estética verdadeiramente atacada pelos nazistas era a da modernidade, a renovação radical do material artístico, a "arte degenerada".

A crítica dos nazistas se estendia sim ao conteúdo "bolchevique" como tendência ideológica na obra de determinados artistas na República de Weimar - como Brecht e Eisler, por exemplo. Mas sob o ponto de vista estético, a tradição da canção operária foi muito útil à campanha musical dos fascistas alemães, com a recolocação de novos textos de júbilo a Hitler em velhas canções proletárias, assim como com a criação de novos hinos nazistas, dentro do mesmo estilo das canções de luta comunistas. Por um lado, a repressão nazista conseguiu extinguir as corporações musicais ligadas aos movimentos de esquerda, que foram de tal modo combatidas, que no período após 1945 , não se reorganizariam com a mesma força de antes de 1933. Por outro lado, houve a incorporação desta tradição da canção de luta alemã à temática nazista. Isto provaria que o ataque a determinadas produções artísticas ligadas à classe operária foi ideológica, mas não estética.

A tonalidade insistentemente definida, o ritmo de marcha, o canto diatônico em uníssono e a repetição de um refrão que pode ser facilmente decorado, tornam a música uma arte viável para atingir grandes massas - uma arma poderosa para quem a domina, quer seja sob o ponto de vista financeiro ou ideológico. Tal estética comprovaria mais uma vez a neutralidade do material musical, capaz de servir a qualquer ideologia, de acordo com o contexto. Tanto é, que os nazistas, além do material estético da canção proletária, também se valeram da tradição musical religiosa (cristã) e romântica da Alemanha, que nada teriam a ver com a ideologia fascista.

13. In: F. PRIEBERG, Musik im NS-Staat, Frankfurt am Main, Fischer, 1982, p. 35.

14. Idem, loc. cit. 
15. Arnaldo Daraya CONTIER, "Memória, história e poder: A sacralização do nacional e do popular na música (1920-1950)", in: Revista Música, São Paulo, Departamento de Música da ECA-USP, 2(1):7, maio 1991.

16. Hanns EISLER, Schriften 1948-1962, Leipzig, Deutscher Verlag für Musik, 1982. G.W. III/2. Gesellschaftliche Grundfragen der modernen Musik, p. 13-25.

17. In: Revista Música Soviética, Moscou, nº 5, 1948.

18. Idem.

19. Mário de Andrade atribui à frase de Glinca o adjetivo "duvidosa", mas mantém-se simpático a ela da mesma forma que posteriormente se encontrariam Jdanov e Camargo Guarnieri: "Lembrando aquela frase duvidosa de Glinca, sobre não serem os compositores eruditos a 'criar', mas o povo, cujo material os compositores recolhem e manipulam, Chostacovich esclarece não significar isso o uso simplório do folclore. O trabalho do compositor soviético consistiria em aprender incessantemente com o povo, apanhar tudo quanto este cria, e ser digno do periodo histórico que está vivendo". Cfr. Mário de ANDRADE, "Prefácio", in: Victor SEROFF, op. cit., p. 14.

20. Arnaldo Daraya CONTIER, op. cit., p. 27.

21. Gilberto MENDES, "Música Moderna Brasilcira c suas Implicações de Esquerda", Revista Música, São Paulo, Departamento de Música da ECA - USP, 2(1):40, maio 1991. Este artigo de Gilberto Mendes fora encomendado anteriormente pela revista Musik und Gesellschaft de Berlim, através de nossa intermediação. Efetuamos a tradução para o alemão c entregamos o texto à Dra. Liesel Markowski, chefe de redação da revista. Ela recusou o artigo, considerando-o racista, por não mencionar a influência do índio no desenvolvimento da cultura musical brasileira. Mais uma prova do atrevimento da ignorância.

22. In: DEUSTCHE DEMOKRATISCHE REPUBLIK. 5. Tagung des Z.K. der Sozialistischen Einheitspartei Deutschlands. Der Kampf gegen Formalismus in Kunst und Literatur, für eine fortschrittliche deutsche Kultur. Berlim, Dietz, março de 1951.

23. Ernst H. MAYER, "Geleitwort zur Zeitschrift Musik und Gesellschaft e Realismus im Musikschaffen", in: Musik und Gesellschaft, nº 1, Berlim, Henschelverlag, março de 1951, p. 1 e 22.

24. In: REVISTA MÚSICA SOVIÉTICA. Relatórios de erros nas avaliações das óperas "A Grande Amizade", "Bogdan Rmelnitsqui" e "De todo Coração" - Resoluções do C.C. do P.C.U.S. Moscou, 28.05.1958. (Original em Russo)

25. Segundo Günter Mayer, "existiram também períodos nos quais o Stálinismo continuava exercendo influências sobre a política musical com suas duradouras consequiências sobre as culturas musicais. Estes perío- 
dos foram o início dos anos 30 na União Soviética, e, ainda mais acentuadamente, o período após 1948 no mesmo país e, nos países socialistas, o período que durou até a década de 60 e o início dos anos 70". Cfr. Günter MAYER, "Revolução na música - As vanguardas de 1200 e 2000", op. cit., p. 15.

26. Bertolt BRECHT, "Was ist Formalismus (1953)", in: Schriften zur Literatur und Kunst. Berlim e Weimar, Aufbauverlag, 1966, Bd. V, p. 328-342.

27. In: Albrecht BETZ, Hanns Eisler, München, text + kritik, 1976, p. 179.

28. Brecht talvez tenha desenvolvido este pensamento a partir de Galileu Galilei - um de seus personagens preferidos - "Se quiser encontrar a verdade, você tem que empregar a fantasia... você tem que brincar de inventar e adivinhar um pouco. Quando estou procurando a verdade, sempre procuro pelo contrário, porque o grande bem e o grande mal sempre estão juntos como galinhas no mercado". In: James RESTON JR., Galileu - uma vida, Rio de Janeiro, José Olympio, 1995, p. 51.

29. A. Contier confirmaria esse processo, onde uma autoridade, devido à própria ignorância, viria desprezar os aspectos da inovação formal na arte: "Lênin opunha-se a todas as tendências da arte moderna, devido a razões mais estéticas do que propriamente político-ideológicas. Em um de seus inúmeros depoimentos, confessou sua 'ignorância' em face das obras dos expressionistas, futuristas, cubistas". In: Arnaldo Daraya CONTIER, op. cit., p. 24.

O texto de Lênin seria o seguinte: "Somos bons revolucionários, mas, não sei por que, nos sentimos obrigados a provar que estamos à altura da cultura moderna. Eu me atrevo a declarar-me um 'bárbaro'. Eu não consigo considerar como manifestações supremas do gênio artístico as obras do expressionismo, do futurismo, do cubismo e de outros 'ismos'. Não os compreendo. Não me proporcionam o menor prazer". Cfr. Flávio KOTHE, "Lênin e a modernidade", in: A Voz da Unidade, São Paulo, 04 a 10/07/1986, p. 17.

30. Poderíamos observar tal fato na entrevista de K. Stockhausen a J. J. de Moraes: "Viu o que a Orquestra de Stuttgart está tocando no Brasil? Beethoven, Mendelssohn, Ravel... tudo bem antigo, velho. Nada de música contemporânea. As pessoas não ouvem música contemporânea e, por isso, por não estarcm acostumados a ela, não gostam. E como as orquestras tocam pouco música moderna, quando fazem isso, tocam mal. Isso é bem sinal da decadência artística. É igual em todo lugar - na Europa e aqui. Até o final do séc. XIX ouvia-se música moderna. Agora é diferente. Veja uma figura como a de Leonard Bernstein. Ele não toca música moderna porque não gosta. E coloca a culpa de não tocá-la, no público. Mas ele tem um gosto horroroso - veja como ele toca Mahler, todo empolado". Cfr. Karlheinz STOCKHAUSEN, Entrevista concedida a 
J. J. de Moraes, in: Revista Música, São Paulo, Departamento de Música da ECA-USP, 1 (1):35-37, maio 1990.

$\mathrm{O}$ argumento de que o povo não entende ou isso não é bom para o povo, ou seja, falar em nome do povo ou do público, seria uma arrogância incomensurável, no sentido de atribuir ao povo, opiniões, desejos ou mesmo um gosto cstético que, na verdade, estariam subordinados à subjetividade pessoal. O exemplo de Bernstein prova que Jdanov não teria sido o último a atacar a modernidade desta maneira. Esse tipo freqüente de atitude, no entanto, por parte de pessoas influentes, sempre acaba sendo um grande empecilho para divulgação da música crudita contemporânea.

31. Se, por um lado, observamos em Antonio Gramsci a utilização do conceito de cosmopolitismo moderno ou avançado mais ou menos neste mesmo sentido de Brecht, o importante filósofo italiano aponta, contudo, para a existência também de um cosmopolitismo tradicional, que exclui as manifestações das classes trabalhadoras nacionais do ordenamento político internacional, (In: Antonio GRAMSCI, Quaderni del Carcere, volume terzo, quaderni 12-29, Giulio Einandi Editore, 1977, p. 1987-89) "mesmo que estas classes trabalhadoras sejam 'cosmopolitas' por programa c objetivo histórico" (In: Antonio GRAMSCI, Quaderni del Carcere, volume secondo, quaderni 6-11, Giulio Einandi Editorc, 1977, p. 795). Hoje vivenciamos, no âmbito cultural, um quadro ainda mais estarrecedor deste tipo de cosmopolitismo tradicional (de classe dominante). Trata-se da nova "paródia do coletivismo" - expressão utilizada por Heiner Müller referindo-se, por exemplo, aos MacDonalds, mas que podemos entendê-la na música como a Disco-music, o Rock, o Funk, o Rap etc, fruto das grandes indústrias de entretenimento, que "fazem dos povos de todos continentes verdadeiros analfabetos musicais" (Hanns Eisler). É o fast-thinking. Essa barbárie vem conseguindo subtrair da música sua essência mais espiritual, assim como seus componentes telúricos, e não só no ocidente como também nas civilizações não européias. O mundo é uma aldeia global, mas o gosto de todas as aldeias é determinado apenas por aquela dominante, que detém o satélite.

32. O estudo para piano Eisler e Webern caminham nos mares do sul de Gilberto Mendes foi encomendado por José Eduardo Martins e estreado $\mathrm{cm}$ seu recital no Schlosstheater im Neuen Palais em Potsdam, RDA, no ano de 1989, alguns meses antes da queda do Muro de Berlim.

33. Ernst H. MAYER, "Geleitwort zur Zeitschrift Musik und Gesellschaft e Realismus im Musikschaffen", op.cit., loc. cit.

34. Hanns EISLER, Musik und Politik- Schriften 1948-1962, Leipzig, VEBDeutscher Verlag für Musik, 1982. III/2, Briefnach Westdeutschalnd, p. 179-193.

35. Segundo Ilma E. de A. Santana, em relação à música para o filme Kuhle Wampe, produzido no início dos anos 30 pelo Partido Comunista Alemão 
(KPD), e neste caso, um exemplo de crítica partidária durante a República de Weimar: "Um trabalhador declara que 'aprecia a música de Eisler', mas que 'não gostou da canção de Helene Weigel' — por sinal um poema de Brecht com música de Eisler, porém num estilo menos 'popular' do que o das canções militantes. Esse desagrado em relação à canção seria talvez um indício da 'dualidade' de Eisler, cuja formação viera de Schönberg (dodecafonismo), enquanto que a militância o obrigava a um estilo mais tradicional ou mais próximo das preferências do partido (tonalidade)". In: Ilma Esperança de Assis SANTANA, O cinema operário na República de Weimar, São Paulo, Editora da Universidade Estadual Paulista, 1993, p. 89.

Contudo, não seria desta vez que Eisler abdicaria das técnicas mais contextualizadas com a modernidade musical de um modo efetivo. Exemplo disto seria a Pequena Sinfonia Op. 29, importante obra dodecafônica inserida ainda em sua 3a. fase - na República de Weimar, escrita em 1932, portanto logo após a composição musical para o filme Kuhle Wampe.

36. In: Alain TOURAINE, Critica da Modernidade, Petrópolis, Vozes, 1994, p. 214-215.

37. Cfr. Manifesto Música Nova, in: Vasco MARIZ, A história da música no Brasil, Rio de Janeiro, Civilização Brasileira, 1983, p. 315.

38. Heiner MÜLLER, Der Spiegel, primeira semana de agosto de 1990.

39. “Apenas a atmosfera de só sentir a alma em si mesma e o jogo sonoro de perceber a si próprio, trata-se, por fim, de algo abstrato e generalizado. Se a dor, a alegria, a saudade deve soar na melodia, então ela terá realmente alma concreta no conteúdo verdadeiro, sob circunstâncias definidas, em situações especiais, acontecimentos, ações. Quando o canto nos desperta a sensação de tristeza, de lamento sobre a perda, então perguntase logo: O que foi perdido?"

Esse era um dos pensamentos de Hegel que Eisler mais gostava de citar, para o qual ele teria o seguinte comentário: "Quando prosseguimos, de maneira crítica, no desenvolvimento de tais pensamentos de Hegel, chegaríamos à conclusão de que os velhos critérios estéticos - como se a música é boa ou má, velha ultrapassada ou original - não servem mais, pois não bastam para nos ajudar na discussão, para qual precisaríamos ainda de outros novos fatores como função social, encargo e responsabilidade". In: Hanns EISLER, Musik und Politik - Schriften 1948-1962. Leipzig, VEB Deutscher Verlag für Musik, 1982. III/2, Briefnach Westdeutschland - V. p. $180-181$.

Em seu texto Hegel e a Música, Günter Mayer discorre sobre alguns aspectos curiosos da concepção musical do grande filósofo alemão. Em cartas à sua mulher, Hegel escreve sobre os eventos musicais a que assistiu durante sua estada de 16 dias em Viena, no outono europeu de 1824. 
Segundo Mayer, os relatos eram dos mais entusiasmados e concentravam-se na arte vocal de Rossini, que para Hegel, correspondia ao espírito da modernidade. Naquela época, o grande compositor da moderna ópera italiana era festejado pelo Zeitgeist dominante, havendo até mesmo escrito duas cantatas, La Santa Alleanza e Il vero Omaggio (1822), para o Congresso de Verona da Santa Aliança, a pedido do principal artífice da Restauração, o estadista austríaco Klemens Wenzel Nepomuk Lothar, Príncipe de Metternich. Enquanto Rossini obtinha um sucesso atrás do outro com suas óperas, Beethoven, o verdadeiro Zeitgeist (sob o ponto de vista da inovação dos materiais musicais), não raramente tinha que lutar pela audição de suas obras. De um modo geral, Hegel parece não ter percebido, também na música, a tensão entre o verdadeiro e o falso Zeitgeist. Cfr. Günter MAYER, "Hegel und die Musik", in: Weltbild Notenbild, zur Dialektik des musikalischen Materials, Leipzig, Reclam, 1978, p. 9-46.

Hegel idolatrava Rossini e ignorava Beethoven. Apesar de tê-lo conhecido, Hegel nunca chegou a escrever uma linha sequer sobre o compositor mais revolucionário de seu tempo. Esta seria mais uma prova da dificuldade - até mesmo entre os intelectuais mais brilhantes de uma época no discernimento sobre os misteriosos e subjetivos critérios da modernidade musical. Como poderíamos delimitar as frontciras científicas da musicologia no discurso verbal? Até onde vai a capacidade da ciência ou da filosofia na compreensão da arte? No entanto, como podemos observar no texto de Edmond Michote, Wagner e Rossini (In: STENDHAL, Vida de Rossini, São Paulo, Companhia das Letras, 1995, p. 455-465), o grande artista Rossini, que não era filósofo, mesmo sem ter as mesmas brilhantes dimensões intelectuais de Hegel, soube, como poucos em seu tempo, avaliar a importância extraordinária da obra de Beethoven.

40. Hanns EISLER, Musik und Politik - Schriften 1924-1948, Leipzig, VEB Deutscher Verlag für Musik, 1985. III/1, Avantgarde-Kunst und Volksfront, p. $397-405$.

Rubens Ricciardi é graduado e mestre pelo Departamento de Música da ECA-USP. Doutorando em Artes na ECA-USP. 